\title{
Haematological Indices as a Measure of Quality of Life Amongst Inmates of Port Harcourt Correctional Institutions
}

\author{
Theresa Awortu Jeremiah", *, Ransom Baribefii Jacob², Zaccheaus Awortu Jeremiah², \\ Ifeoma Bessie Enweani-Nwokelo ${ }^{1}$, Chris Anyamene ${ }^{3}$ \\ ${ }^{1}$ Department of Medical Laboratory Science, Nnamdi Azikiwe University, Nnewi Campus, Nnewi, Nigeria \\ ${ }^{2}$ Department of Medical Laboratory Science, River State Univeristy, Port Harcourt, Nigeria \\ ${ }^{3}$ Department of Microbiology, Nnamdi Azikiwe University, Awka, Nigeria \\ ${ }^{4}$ Hartfield International Biomedical Center, Houston, Texas, USA
}

Email address:

zacjerry39@gmail.com (T. A. Jeremiah)

${ }^{*}$ Corresponding author

\section{To cite this article:}

Theresa Awortu Jeremiah, Ransom Baribefii Jacob, Zaccheaus Awortu Jeremiah, Ifeoma Bessie Enweani-Nwokelo, Chris Anyamene. Haematological Indices as a Measure of Quality of Life Amongst Inmates of Port Harcourt Correctional Institutions. Biomedical Sciences. Vol. 7, No. 3, 2021, pp. 74-80. doi: 10.11648/j.bs.20210703.13

Received: July 8, 2021; Accepted: July 16, 2021; Published: August 9, 2021

\begin{abstract}
Restriction to health care and poor medical attention to inmates in correctional institutions in Port Harcourt has provided a gap in knowledge about their general health as well as their haematological indices status. Haematological indices are derivatives of complete blood count (CBC) used in the evaluation of overall health and detect a wide range of disorders, measure several components and features in the blood. This cross sectional study was aimed at determining haematological indices as a measure of quality of life amongst inmates of Port Harcourt Correctional Institution. One hundred and fifty (150) adults and twenty-eight (28) juveniles making a total of one hundred and seventy eight (178) adults and juveniles of both sexes participated in this study. Two milliliters (2mls) of blood was collected from each participant and dispensed into an EDTA anticoagulant bottle and used for the haematological investigations. Results obtained shows Mean $\pm \mathrm{SEM}$ of $\mathrm{Hb}(12.87 \pm 0.10$ $\mathrm{g} / \mathrm{dl} ; 95 \% \mathrm{CI}, 12.69-13.06)$, WBC $\left(6.63 \pm 0.16 \times 10^{9} / \mathrm{L} ; 95 \%\right.$ CI, $\left.6.32-6.93\right)$, Neutrophils (43.99 $\pm 0.77 \% ; 95 \%$ CI of $\left.42.47-4.51 \%\right)$ while the Mean \pm SEM of Lymphocytes was $44.75 \pm 0.79 \%$ at $95 \%$ CI of $43.19-46.31$ and CMX was $10.55 \pm 0.30 \%$, at $95 \% \mathrm{Cl}$ of 9.95-11.15). Haematological parameters of the inmates showed a significant $\mathrm{Hb}$ level among the males and between age 25-34 years at a significant level of $\mathrm{P}<0.0001$ respectively. The percentage of the lymphocyte, the CMX within these age group was also very significant at $\mathrm{P}<0.0001$ respectively. The reduced blood level, with the raise lymphocyte and CMX is a clear indication of poor health status and the presence of underlying infection although the findings cannot be adequately substantiated.
\end{abstract}

Keywords: Haematological Indices, Inmates, Correctional Institution, Port Harcourt

\section{Introduction}

Haematological indices are parameters which identify the characteristics of the red blood cells that are circulating at the time that the sample was collected. They are calculated parameters that are part of an automated blood count report and are primarily used to assist with differentiation of anaemias, serve as quality control checks. A complete blood count (CBC) analysis is used to evaluate and ascertain overall health status, detect a wide range of disorders and measure several components and features in the blood [1-3, 15]. In many disease conditions, specific symptoms of a medical condition may not be present and haematological changes in the Complete blood count may be the only finding present thus information on haematological parameters are however very important.

Imprisoned people have usually a poor health status in comparism with the general population [16]. This health disparity has been attributed to various causes such as alcohol misuse, intravenous drug use, smoking, malnutrition 
and inactivity which could increase the risk of morbidity, mortality and mental disorders [4, 17, 19]. Prolonged or lifelong exposure of the immune system to environmental risk [17] also affect the white blood cells especially infections. Loss of lymphoid tissue during aging is accompanied by immune alteration and decline in the function of the immune system increases susceptibility to infections. Lymphocytes are WBCs in the immune system [2]

Health is one of the key indicators of well-being of a society and prisons serve as mirrors of society [5, 18]. Prisons and jail environments are increasingly being recognized as settings in which society's diseases are concentrated [6]. Prisons are not closed worlds, many people enter and leave prisons every day and many stay only for a short period in prison and return to their family, so this is a public health concern [7]. Prisoners are therefore potential reservoirs of infection to uninfected entrants and the general population upon regaining freedom [8, 9, 5, 17]. Prisoners form part of criminal justice system and it is estimated that over 10.1 million people are in correctional institutions worldwide, mostly as pretrial detainees/remand prisoners or as sentenced prisoners [10]. Almost half of these are in the United States (2.29million), Russia (0.81million) and China 1.65million) sentenced prisoners, [11]. In Africa, the median prison population rates from $324 / 100,000$ of the national population in South African countries to 52/100,000 in West African Nations [11]. Prisons and jails represent unique and challenging environments, and are mostly constructed to maximize public safety but not to minimize the transmission of disease or to efficiently deliver health care $[12,18]$.

Restriction to health care and poor medical attention to inmates in correctional institutions in Port Harcourt has provided a gap in knowledge about their general health as well as their haematological indices status. Thus this work was aimed at assessing haematological indices such as haemoglobin concentration $(\mathrm{Hb})$, white blood cell (WBC) count and differentials as a measure of quality of life amongst inmates in Port Harcourt Correctional Institutions.

\section{Material and Methods}

\subsection{Study Population}

The study population consisted of adult inmates and juveniles of both sexes from the Port Harcourt Maximum Prisons and the Juvenile Remand Home. One hundred and fifty adults (150) and twenty-eight (28) juveniles participated in this study. The study population therefore comprised a total of one hundred and seventy eight (178) adults and juveniles of both sexes.

\subsection{Study Design}

A Cross Sectional Design was used in this study. Samples were collected randomly after obtaining an informed consent from each of the inmates according to IBL Services and Regulations. Each of the inmates from both study areas were administered structured questionnaires to access information bothering on their health status, Two milliliters ( $2 \mathrm{mls})$ of blood was aseptically collected and dispensed into an EDTA anticoagulant bottle and used for the haematological investigations.

\subsection{Procedure for Haematological Indices}

Automated Blood Analyzer (3-part) was employed for the analysis of haematological indices of inmates. The instrument is computerized and highly specialized. It utilizes Flow cells, Photometers and Apertures in order to analyze different elements in the blood. The cell counting component counts the numbers and types of different cells within the blood. A special photometer called the haemoglobinometer measures the amount of haemoglobin. This is done by adding a diluent that lyses the red blood cells which is then pumped into a spectro-photometric measuring cuvette. The change in the colour of the lysate equates to the haemoglobin content of the blood. The results are printed out or sent to a computer for review.

Blood cell counting occurs by flow cytometry when a small amount of the specimen is aspirated, diluted and passes through an aperture and a laser flow cell. Sensors count and identify the number of cells passing through aperture. The two main types of sensors used are the laser light detectors and electrical impedance. The instrument determines the type of blood cell by analyzing data about the size and aspects of lights as they pass through the cells.

\subsection{Sample Collection and Analysis}

Venous blood samples $(2 \mathrm{mls})$ were collected into a test tube containing anticoagulant (EDTA) and gently mixed to stop it from clotting. The samples were quietly transported to the laboratory for the analysis to be carried out with the Automated Haemo-Analyser. Samples were analyzed in accordance with manufactures manual.

\subsection{Statistical Analysis}

All statistical tests conducted were 2-tailed, and probability value of $<0.05$ was used as the threshold for declaring statistical significance. Data management and statistical analyses were conducted using SPSS software version 25.0 (SPSS Inc., Chicago, USA). Graphical representations were carried out using the JMP statistical discovery ${ }^{\mathrm{TM}}$ software version 14.3 (SAS Institute, Cary, NC, USA).

\section{Results}

As shown in Table 1 and figures 1-5, the Mean \pm SEM of the five haematological parameters as follows: $\mathrm{Hb}$ $(12.87 \pm 0.10 \mathrm{~g} / \mathrm{dl} ; \quad 95 \% \quad \mathrm{CI}, \quad 12.69-13.06), \quad$ WBC $\left(6.63 \pm 0.16 \times 10^{9} / \mathrm{L} ; 95 \% \quad \mathrm{CI}, \quad 6.32\right.$ - 6.93), Neutrophils $(43.99 \pm 0.77 \% ; \quad 95 \% \quad$ CI of $42.47-4.51 \%)$ while the Mean \pm SEM of Lymphocytes was $44.75 \pm 0.79 \%$ at $95 \%$ CI of 43.19-46.31 and CMX was $10.55 \pm 0.30 \%$, at $95 \% \mathrm{Cl}$ of 9.95 11.15). The Mean distributions of these parameters were also represented in tables and figures (Box plot). 
Table 1. Mean \pm SEM of Haematological Parameters of Prlison Inmates.

\begin{tabular}{|c|c|c|c|c|c|}
\hline \multirow{2}{*}{ Characteristic } & \multicolumn{2}{|r|}{$\mathrm{Hb}(\mathrm{g} / \mathrm{dl})$} & \multicolumn{3}{|c|}{ WBC $\left(\times 10^{3} / \mathrm{ml}\right)$} \\
\hline & $\mathbf{N}$ & Mean \pm SEM & P-value & Mean \pm SEM & P-value \\
\hline \multicolumn{6}{|l|}{$\overline{\text { Sex }}$} \\
\hline Female & 33 & $12.13 \pm 0.21^{\mathrm{a}}$ & & $6.05 \pm 0.36$ & \\
\hline Male & 145 & $13.04 \pm 0.10^{\mathrm{b}}$ & $0.0002 * *$ & $6.76 \pm 0.17$ & $0.079^{\mathrm{ns}}$ \\
\hline \multicolumn{6}{|l|}{ Age Group (Years) } \\
\hline$<15$ & 13 & $11.37 \pm 0.33^{\mathrm{a}}$ & & $6.22 \pm 0.58$ & \\
\hline $15-24$ & 49 & $12.94 \pm 0.17^{\mathrm{b}}$ & & $6.75 \pm 0.30$ & \\
\hline $25-34$ & 60 & $13.30 \pm 0.15^{b}$ & & $6.49 \pm 0.27$ & \\
\hline $35-44$ & 28 & $12.67 \pm 0.22^{\mathrm{b}}$ & & $6.62 \pm 0.40$ & \\
\hline $45-54$ & 12 & $12.56 \pm 0.34^{\mathrm{ab}}$ & & $6.77 \pm 0.60$ & \\
\hline $55+$ & 16 & $12.89 \pm 0.30^{\mathrm{b}}$ & $<0.0001 * * * *$ & $7.03 \pm 0.52$ & $0.903^{\mathrm{ns}}$ \\
\hline \multicolumn{6}{|l|}{ Educational Status } \\
\hline No Formal Education & 18 & $12.48 \pm 0.30$ & & $6.54 \pm 0.49$ & \\
\hline Primary School & 45 & $12.82 \pm 0.23$ & & $6.21 \pm 0.31$ & \\
\hline Secondary School & 93 & $13.00 \pm 0.12$ & & $6.69 \pm 0.21$ & \\
\hline Tertiary Education & 22 & $12.76 \pm 0.24$ & $0.399^{\mathrm{ns}}$ & $7.28 \pm 0.44$ & $0.248^{\mathrm{ns}}$ \\
\hline
\end{tabular}

Table 1. Continued.

\begin{tabular}{|c|c|c|c|c|c|c|}
\hline \multirow{2}{*}{ Characteristic } & \multicolumn{2}{|c|}{ Neutrophil (\%) } & \multicolumn{2}{|c|}{ Lymphocyte (\%) } & \multicolumn{2}{|l|}{ CMX (\%) } \\
\hline & Mean \pm SEM & P-value & Mean \pm SEM & P-value & Mean \pm SEM & P-value \\
\hline \multicolumn{7}{|l|}{ Sex } \\
\hline Female & $44.42 \pm 1.80$ & & $43.85 \pm 1.84$ & & $10.58 \pm 0.71$ & \multirow{2}{*}{$0.969^{\mathrm{ns}}$} \\
\hline Male & $43.89 \pm 0.86$ & $0.788^{\mathrm{ns}}$ & $44.95 \pm 0.88$ & $0.589^{\mathrm{ns}}$ & $10.54 \pm 0.34$ & \\
\hline \multicolumn{7}{|l|}{ Age Group (Years) } \\
\hline$<15$ & $44.08 \pm 2.85$ & & $40.08 \pm 2.78^{\text {ad }}$ & & $15.77 \pm 1.03^{\mathrm{a}}$ & \multirow{6}{*}{$0.001 * * *$} \\
\hline $15-24$ & $44.14 \pm 1.47$ & & $44.49 \pm 1.43^{\mathrm{a}}$ & & $11.57 \pm 0.53^{\mathrm{b}}$ & \\
\hline $25-34$ & $42.58 \pm 1.33$ & & $47.58 \pm 1.29^{b}$ & & $09.70 \pm 0.48^{b}$ & \\
\hline $35-44$ & $42.89 \pm 1.94$ & & $47.89 \pm 1.90^{\mathrm{b}}$ & & $09.21 \pm 0.70^{b}$ & \\
\hline $45-54$ & $47.92 \pm 2.97$ & & $36.50 \pm 2.90^{\mathrm{c}}$ & & $09.17 \pm 1.07^{b}$ & \\
\hline $55+$ & $47.67 \pm 2.57$ & $0.387^{\mathrm{ns}}$ & $39.38 \pm 2.51^{\mathrm{cd}}$ & $0.001 * * *$ & $09.75 \pm 0.93^{\mathrm{b}}$ & \\
\hline \multicolumn{7}{|l|}{ Educational Status } \\
\hline No Formal Education & $43.56 \pm 2.44$ & & $42.33 \pm 2.49$ & & $11.28 \pm 0.95$ & \multirow{4}{*}{$0.541^{\mathrm{ns}}$} \\
\hline Primary School & $42.98 \pm 1.54$ & & $45.89 \pm 1.58$ & & $10.89 \pm 0.60$ & \\
\hline Secondary School & $44.11 \pm 1.07$ & & $44.72 \pm 1.10$ & & $10.47 \pm 0.42$ & \\
\hline Tertiary Education & $45.91 \pm 2.20$ & $0.745^{\mathrm{ns}}$ & $44.50 \pm 2.26$ & $0.689^{\mathrm{ns}}$ & $09.59 \pm 0.86$ & \\
\hline
\end{tabular}

All statistical tests conducted were 2-tailed, and probability value of $<0.05$ was used as the threshold for declaring statistical significance. Data management and statistical analyses were conducted using SPSS software version 25.0 (SPSS Inc., Chicago, USA). Graphical representations were carried out using the JMP statistical discovery ${ }^{\mathrm{TM}}$ software version 14.3 (SAS Institute, Cary, NC, USA).

SEM: Standard error of mean.

Within each Characteristic, means \pm SEM with different superscripts are significantly different at $p<0.05$.

Significance Level: $*=p<0.05 ; * *=p<0.01 ; * * *=p<0.001 ; * * * *=p<0.0001 ;$ ns $=$ Not Significant

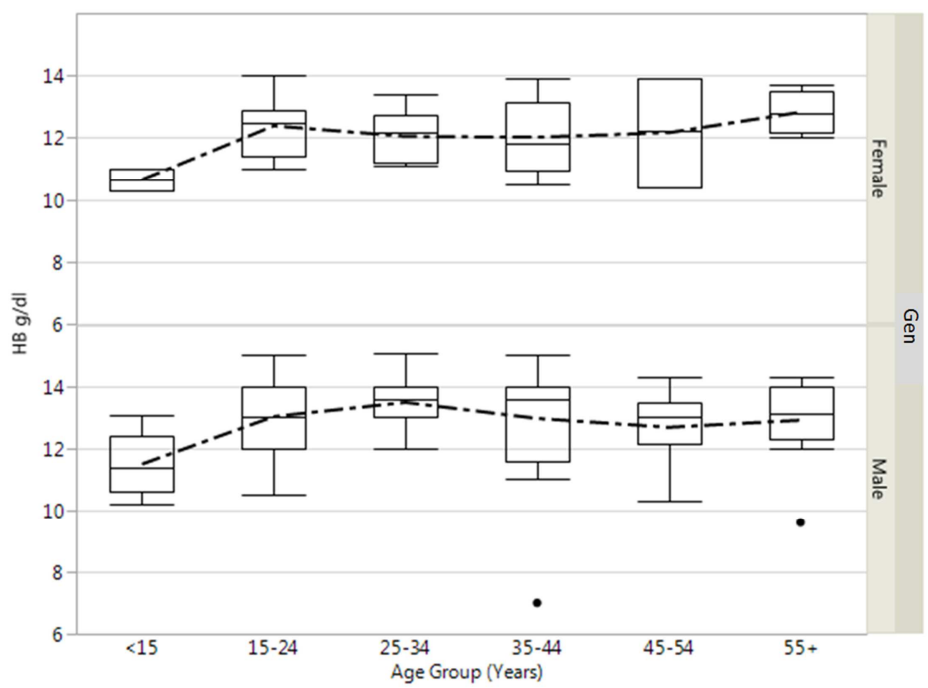

Figure 1. Boxplot of Hemoglobin (g/dl) Level of Inmates by Gender and Age Group. 


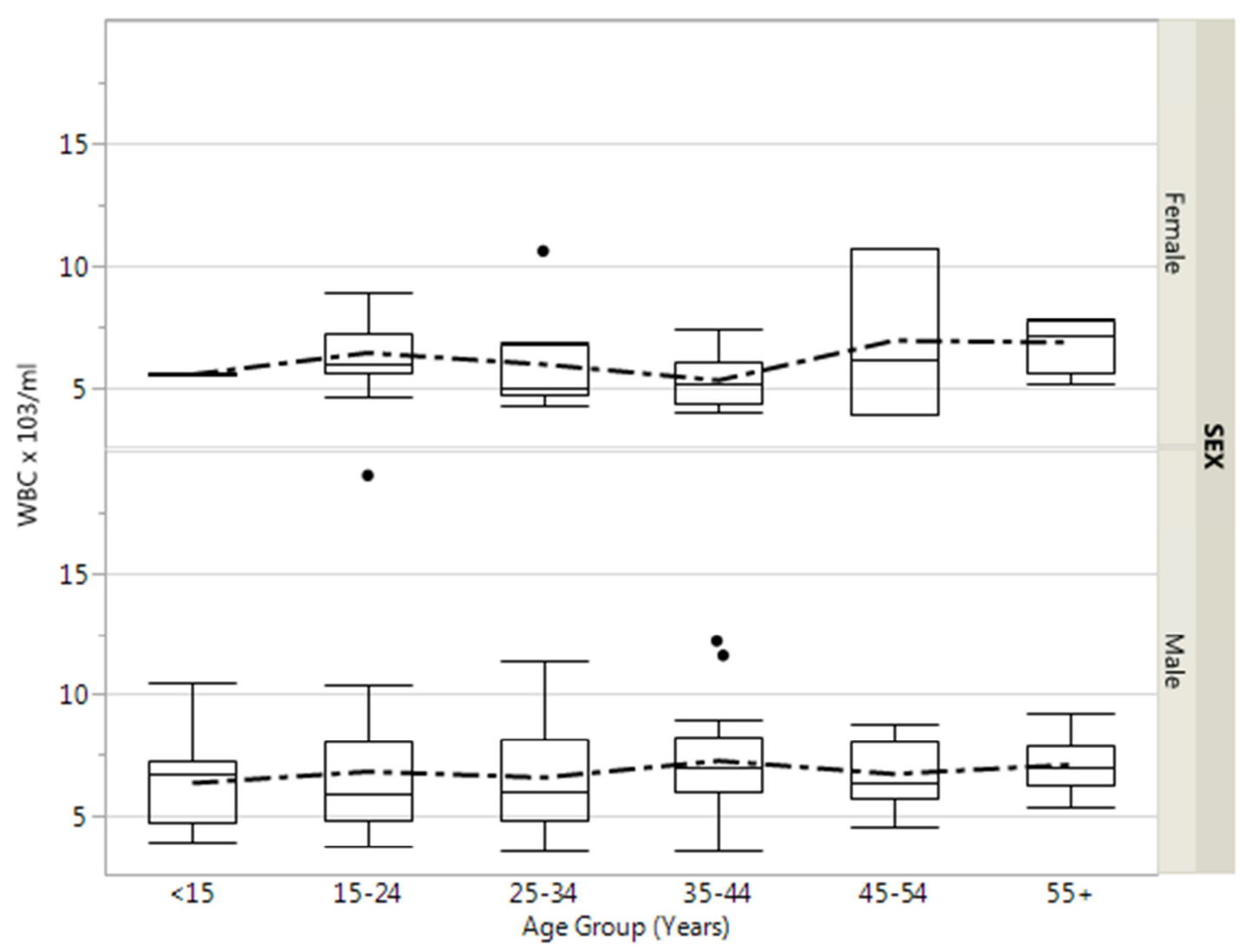

Figure 2. Boxplot of WBC $\left(\times 10^{3} / \mathrm{ml}\right)$ Level of Inmates by Gender and Age Group.

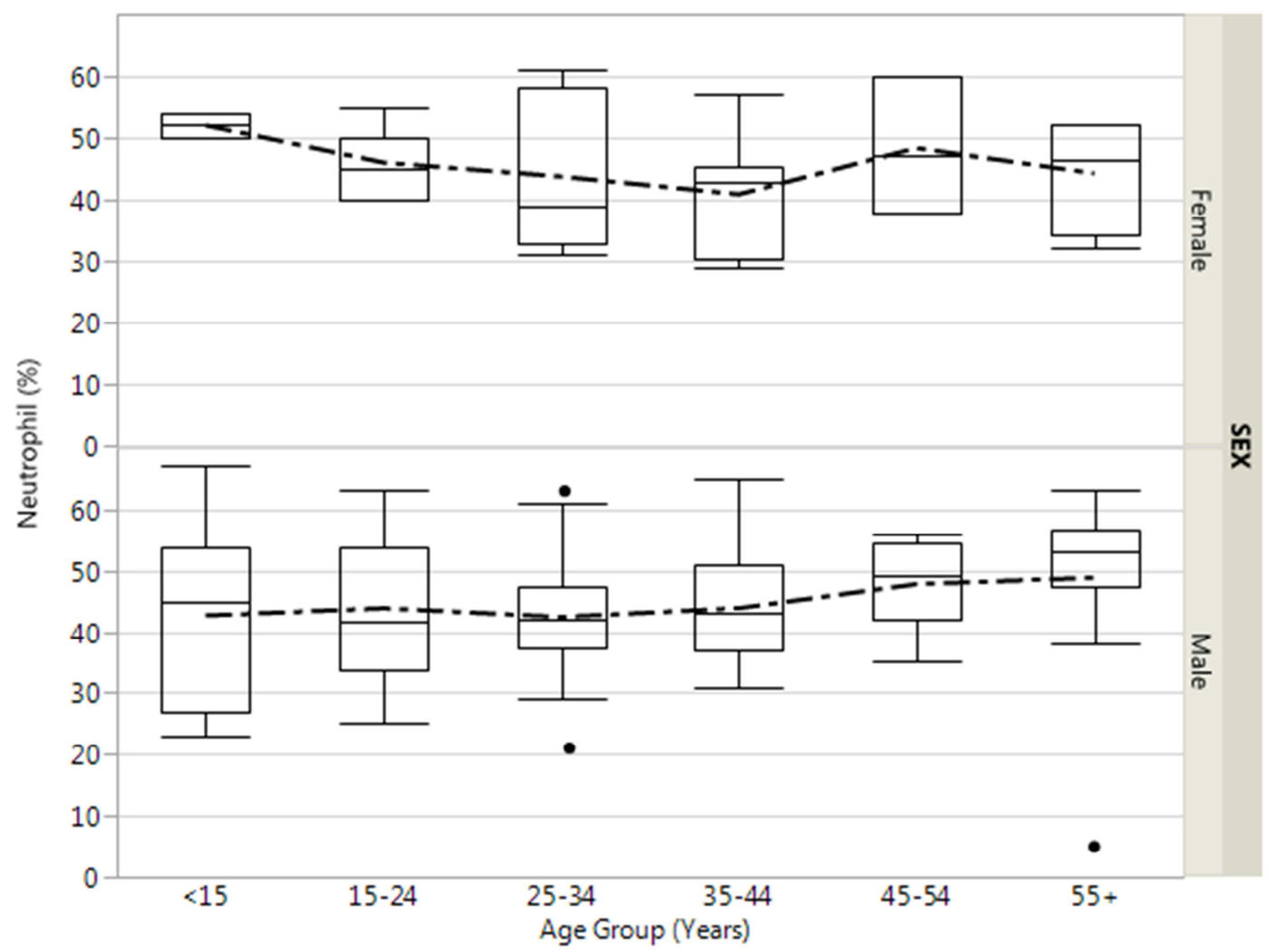

Figure 3. Boxplot of Neutrophil (\%) of Inmates by Gender and Age Group. 


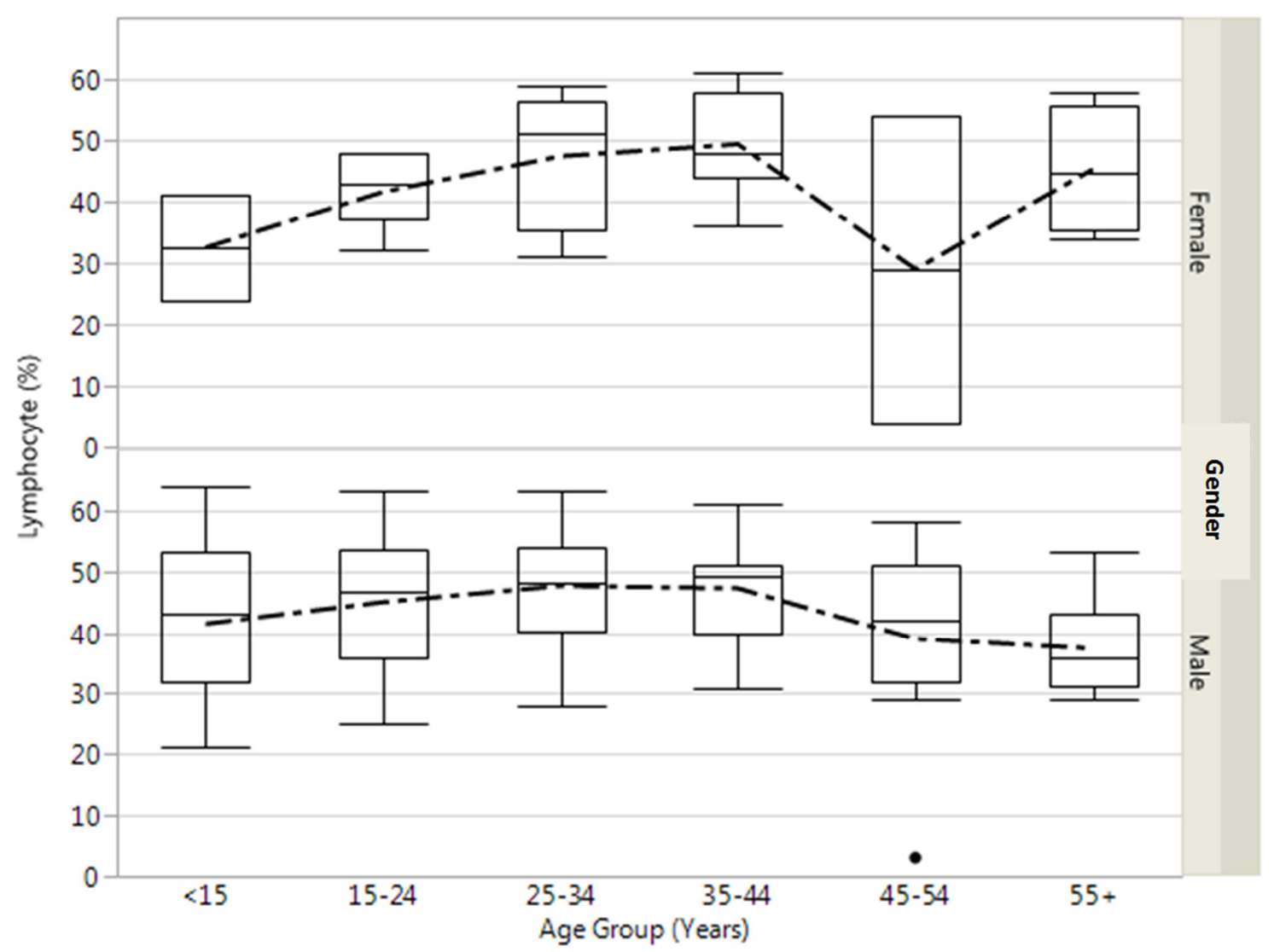

Figure 4. Boxplot of Lymphocyte (\%) of Inmates by Gender and Age Group.

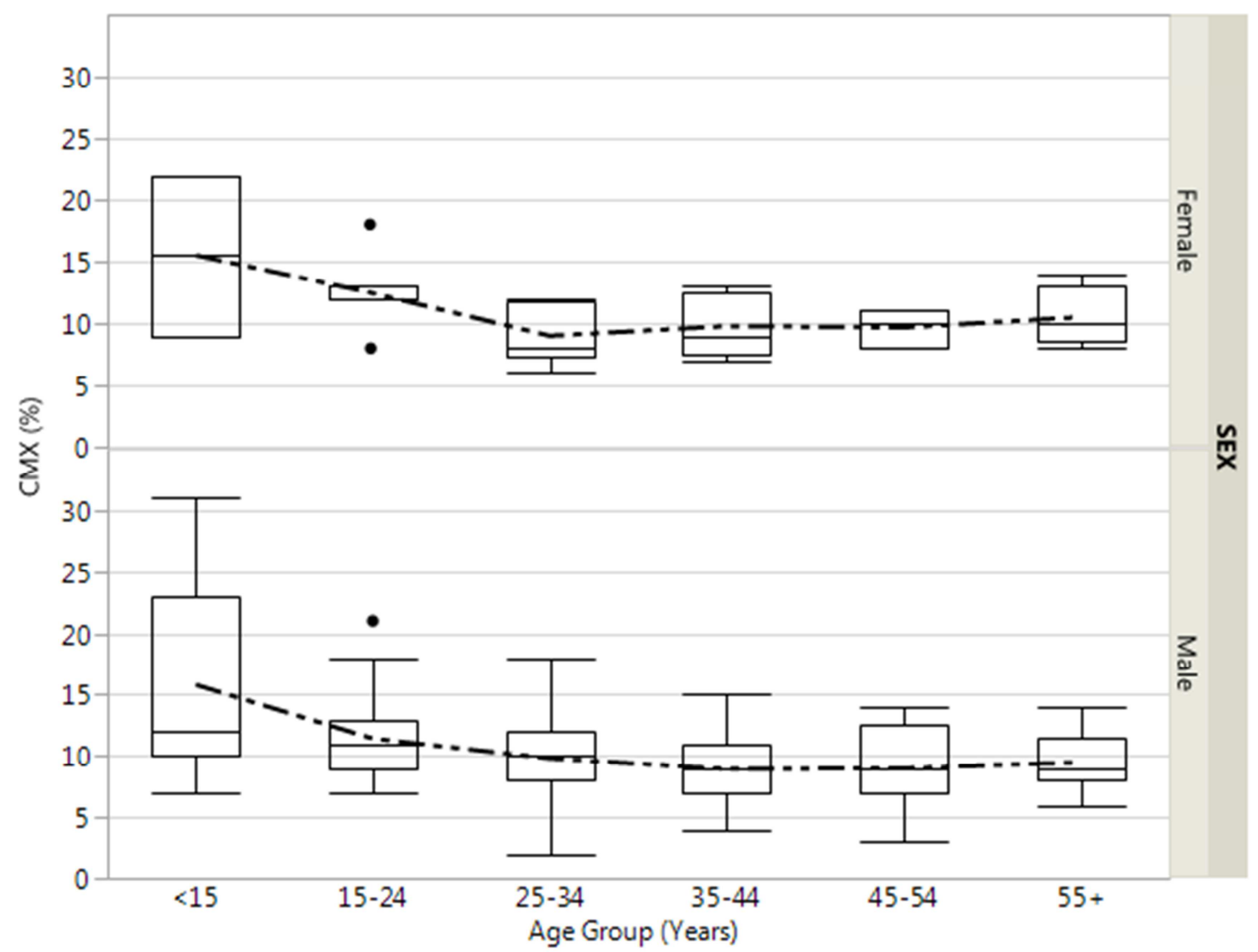

Figure 5. Boxplot of CMX (\%) of Inmates by Gender and Age Group. 


\section{Discussion}

Haematological indices as a derivative of complete blood count are sure index for the assessment of the health status of individuals. Parameters such as haemoglobin concentration $(\mathrm{Hb})$, White blood cells and differential are used in assessing the oxygen carrying capacity of blood as well as establishing the immune status of the individual assessed. The haematological parameter of the inmates showed a significant $\mathrm{Hb}$ level among the males and between age 25-34 years at a significant level of $\mathrm{P}<0.0001$ respectively with male values being significantly higher than that of females.

This finding agrees with the findings of Kouame et al., [13] who reported that red blood cell and haemoglobin concentration were significantly higher amongst inmates especially with regards to sex (males and females) in Grand Bassam prison Ivory coast. Also in agreement with the findings of Lokpo et al., [14] who reported similar values in apparently healthy officers of the Central Prisons in the Ho municipality and use the values obtained in classification of anaemias to include normocytic normochromic, microcytic hypochromic and other rare forms such as microcytic mormochromic, normocytic hypochromic and macrocytic normochromic anaemias.

The values obtained in this study could be due to events of malnutrition triggering inflammatory processes that results in the production of Cytokines secreted by macrophages. The production of cytokines may further sponsor a decreased erythropoietic production, leading to blockage in the reticuloendothelial transfer of iron in the developing red Blood Cells. Furthermore, poor dietary intake of haematinics such as iron, folate and vitamin B12 that are naturally supplied in diets could be responsible for the reported values in this study.

The percentage of the lymphocyte, the CMX within this age group was also very significant at $\mathrm{P}<0.0001$ respectively. The reduced blood level, with the raise lymphocyte and CMX is a clear indication of described malnutrition, poor health status [16] and the presence of underlying infection although the findings cannot be adequately substantiated. This is also in agreement with the findings of Kouame et al., [13] who reported higher values for Lymphocytes and CMX resulting in lymphocytosis, thrombocytopenia and macrocytosis which are disorders arising due to precarious nutritional status weakening and causing depression of immune functions.

Inmates in prisons usually show signs of malnutrition [17, 19] and malnutrition are usually accompany with inflammation, decreased in serum albumin, muscle protein wasting and increased proliferation of T-Lymphocytes and this further explains the observed rise in lymphocytes count in this study.

\section{Conclusion}

Haematological parameter of the inmates showed a significant $\mathrm{Hb}$ level among the males and between the ages of 25-34 years at a significant level of $\mathrm{P}<0.0001$ respectively. The percentage of the lymphocyte, the CMX within this age group was also very significant at $\mathrm{P}<0.0001$ respectively. The reduced blood level, with the raise lymphocyte and CMX is a clear indication of described malnutrition, poor health status and the presence of underlying infection although the findings cannot be adequately substantiated.

\section{References}

[1] George-Gay B. and K. Parker (2003). Umderstanding the complete blood count with differential, Journal of Perianeth Nurse; g 18 (2): 96-114.

[2] Valiathan R, Ashman M. and D. Asthana (2016). Effects of ageing on the immune system: infants to Edgerly. Scandianavian Journal of Immunology 83 (4) 255-266.

[3] Jacob, R. B., Mba, C. O., \& Iduh, P. D (2020). Haematological Alterations among Cement Loaders in Port Harcourt, Nigeria, Asian Journal of Medicine and Health, 18 (7): $1-8$.

[4] Mannocci A, Masala D., Mipatrini D., Rizzo J, Meggiolaro S, D. Thiene; and G. LaTorre (2015). The relationship between physical activity and quality of life in prisons: A pilot study. Journal of Preventive Medicines Hygiene 55 (4): E172-E175.

[5] Math SB., Murthy P., Parthasarthy R., Kumar CN., and S. Madhusudhan (2011). Minds imprisoned: Mental Health care in prisons. National Institute of Mental Health Neuro Sciences 74: $1-3$.

[6] Fazel S. and Danegh J. (2002). Serious mental disorder in 23,000 prisoners: a systematic review of 62 surveys. Lancet, $359,545-550$.

[7] Hammett TM (2006). HIV/AIDs and other infectious diseases among correctional inmates: transmission, burden and an appropriate response. American Journal of Public Health 96 (6): 974-978.

[8] Senok A. C. and Botta G. A. (2006). Human immunodeficiency virus and hepatitis virus infection in correctional institutions in Africa: Is this the neglected source of an epidemic? Journal of Medical Microbiology 55: 481482 .

[9] Adoga MP, Banwart EB, Forbi JC, Numzing L, Pam CR, Gyar SD, Agabi YA and SM Agwale (2009). Human Immunodeficiency Virus, Hepatitis B Virus an Hepatitis C Virus: Sero-prevalence, co-infection and risk factors among prison inmates in Nasarawa State, Nigeria. Journal of Infection in Developing Countries 3 (7): 539-547.

[10] Walmsley Roy (2012). World prison population list. International centre for Prison studies. $10^{\text {th }}$ edition. Retrieved from www.prisonstudies.org. on $9^{\text {th }}$ June 2021.

[11] Walmsley R. (2005). World prison population list, $6^{\text {th }}$ Edition pp. 1-6, King's College London: International Center for Prison Studies. World Prison Briefs. 1-6. 
[12] Culbert G. J. (2011). Understanding the Health needs of incarcerated men living with HIV/AIDS: A primary Health Care Approach. Journal of the American Psychiatric Nurses Association 17 (2): 158-170.

[13] Kouamé, A. R., N'dia. K. F. \& Yapo, A. P. (2016). Assessment of Nutritional Status and Hematologic Profile of Inmates in Grand Bassam Prison (Ivory Coast), World Journal of Pharmaceutical Research 5 (8), 1546-1555.

[14] Lokpo, S. Y., Osei-Yeboah, J., William, K. B. A., Owiredu, P. A., Kortei, N. K., Mensah, D., Peter, N et al., (2020). Evaluation of dietary patterns and haematological profile of apparently healthy officers of the Central Prisons in the Ho municipality. A cross sectional study, Scientific African, 7, e00284.

[15] Adhra Al-Mawali, Avinash Daniel Pinto, Raiya Al-Busaidi, Rabab H. Al-Lawati, Magdi Morsi (2018). Comprehensive haematological indices reference intervals for a healthy Omani population: First comprehensive study in Gulf Cooperation Council (GCC) and Middle Eastern countries based on age, gender and ABO blood group comparison PLoS ONE 13 (4): e0194497. https://doi.org/10.1371/journal. pone.0194497.
[16] Kouyoumdjian, F., Schuler, A., Matheson, F. I. and Hwang, S. W. (2016). Health status of prisoners in Canada: Narrative review. Can Fam Physician, 62 (3): 215-22. PMID: 27427562; PMCID: PMC4984599.

[17] Otuu, F. C. and Shu, E. N (2019). Prevalent Diseases among Inmates in Three Federal Prisons in South-East Geopolitical Zone of Nigeria: A Peep into the Environmental Factors, Journal of Environmental Science and Public Health, 3 (1), 10-24 doi: 10.26502/jesph.96120044.

[18] Nwefoh, E., Aguocha, C. M., Ryan, G. et al. (2020). Depression and experience of incarceration in North Central Nigeria: a situation analysis at Makurdi medium security prison. International Journal of Mental Health Systems, 14, 76 https://doi.org/10.1186/s13033-020-00408-0.

[19] Wondimu, W., Girma, B., Sinaga, M., and Taye, A.(2021). Undernutrition and associated factors among incarcerated people in Mizan prison institute, southwest Ethiopia. PLoS ONE, $\quad 16 \quad$ (5), $\quad$ e251364 https://doi.org/10.1371/journal.pone.0251364. 